\title{
"The Struggle to Sell Survival": Family Fallout Shelters and the Limits of Consumer Citizenship
}

\author{
Thomas Bishop
}

In 1961 families across the United States witnessed the sudden growth of one of the most remarkable consumer products of the Cold War: the home fallout shelter. This article charts the rise of domestic sales for home fallout shelters between 1961 and 1963, the growth in the number of shelter salesmen, the public backlash against their sales techniques, and the eventual decline of the home shelter market. The story of the family fallout shelter exposes the limitations of consumer capitalism in mobilizing and sustaining popular support for national security policy. Questioning the validity of the product being sold and the trustworthiness of the person pitching it, homeowners challenged the citizen-consumer ideal that supposedly went hand-in-hand with the state sanctioned vision of privatized survival.

We all know how deadly and devastating radioactive fallout is to every living thing. When our enemy attacks, what will you do? Have YOU as the head of your family made adequate preparations so that you and your loved ones will SURVIVE? You carry life insurance What have you done about LIFE ASSURANCE?

Florida Survival Shelters, "A family needs a survival shelter to remain a family"

(September 1961) ${ }^{1}$

Why the hell would I want to buy a tomb for the wife and kid? Tom Baulk, Letter to the Office of Civil Defense (November 1961) ${ }^{2}$

In September 1961, business boomed for the fallout shelter salesman. In the words of Frank F. Norton, owner of the Chicago-based home shelter manufacturing company Atomic Shelter Corporation, profits had never been so healthy. "My best salesmen," Norton enthused to a reporter from Time magazine, "are named Khrushchev and Kennedy."3 Since President Kennedy's call during the July 1961 Berlin address for citizens to take the necessary steps to protect themselves and their families from a potential nuclear confrontation with the Soviet Union, Norton, alongside scores of shelter suppliers across the United States, had been inundated with inquiries from local residents requesting information about how to purchase and

I want to express my deepest gratitude to Sarah Phillips, Brooke Blower, the editorial assistants, and the anonymous reviewers for their comments and interventions. I am especially indebted to the sage words of wisdom from Bevan Sewell and Anthony Hutchinson, and the feedback of Daniel King, Jimmy Brookes, Steven Gallo, and Mark Eastwood. Thanks go lastly to my academic comrades Alex Bryne, Lorenzo Costaguta, and Michelle Green.

${ }^{1}$ Florida Survival Shelters, A Family Needs a Survival Shelter to Remain a Family, Sept. 21, 1961, box 27, Central Files 1961-1968, Record of the Defense Preparedness Agency, Office of Civil Defense (OCD), RG 397, National Archives and Records Administration, College Park, Maryland [hereafter NARA II].

${ }^{2}$ Tom Baulk to Office of Civil Defense, Sept. 9, 1961, Shelters and Vulnerability Reduction Jan.-Mar., box 24, Central Files 1961-1968, Record of the Defense Preparedness Agency, OCD, NARA II.

3“Civil Defense: Boom to Bust," Time, May 18, 1962, 20.

(C) The Author(s) 2019. Published by Cambridge University Press 
build family shelters in their own backyards and basements. ${ }^{4}$ In Chicago, one branch of Sears, Roebuck and Company recorded that during September 1961, an estimated four hundred shoppers visited their model home shelter exhibition each week. Meanwhile, Norton's cross-town rival Leo Hoegh, former director of the Office of Civil and Defense Mobilization (OCDM) and now vice-president of the Wonder Building Corporation, claimed to be selling two hundred shelters a week. ${ }^{5}$ In the autumn of 1961, as the Berlin Wall went up and the Soviet Union broke a moratorium on nuclear testing, the fallout shelter salesman stood primed to become the business success story of the decade.

With demand for family shelters at an all-time high, Frank Norton decided to invest in local advertising to make his product stand out in an increasingly congested marketplace. Running ads in the Chicago Tribune throughout the fall and winter of 1961 and into the summer of 1962, Norton pitched nuclear protection directly to middle-class homeowners: "For just 200 dollars you too can have a fall-out shelter that you can enjoy!" Not only did Norton's Atomic Shelter Corporation offer "affordable state of the art protection [that] every family needs," Norton's shelters also had a "dual purpose," providing "a year-round room for you to pursue your favorite hobbies ... woodwork, photography you name it!... Or just think of it as a den to escape the wife and kids." ${ }^{6}$ But Norton's vision of Chicago's homeowners rushing to buy his brand of family fallout shelter was exceptionally short-lived. Over the course of the next two years, an estimated six hundred shelter companies across the United States filed for bankruptcy. ${ }^{7}$ By the end of 1962, Norton's firm had collapsed. "The market is now dead," Norton informed Time magazine; "the manufacturers have had it."

This article charts the rise and fall of domestic sales for home fallout shelters from the anticipated market boom in 1961 to bust by 1963. A close analysis of business records, trade publications, personal histories of salesmen, and consumer reactions reveals the halting and largely improvised process through which the federal government outsourced civil defense programs to local business interests. Scholarship on the family fallout shelter has flourished in recent decades, but historians have yet to engage with the difficulties and complications of selling survival. ${ }^{9}$ While one recent study has highlighted the architects who designed fallout shelters in cooperation with federal civil defense authorities, scholars should also consider the critical role of small-scale promoters, private businesses, and individual sellers in shaping and delivering the policy of do-it-yourself survival. ${ }^{10}$

An investigation of the growth in the number of shelter salesmen, the public backlash against their techniques, and the decline of the market reveals how commercial interests shaped

\footnotetext{
4"Shelter Boom," Newsweek, Sept. 18, 1961, 32.

${ }^{5}$ Letters from Frank Norton to the Office of Civil Defense are in box 6, Correspondence Sept.-Nov. 1961, Record of the Defense Preparedness Agency, OCD, NARA II. Note that the correspondence back from the OCD to Norton is absent from the records.

${ }^{6}$ Clippings of the advertisements were collected by Margaret Mead when researching her article "Are Shelters the Answer?," box I 104, Margaret Mead Papers, Manuscript Division, Library of Congress, Washington, DC.

${ }^{7}$ Kenneth D. Rose, One Nation Underground: The Fallout Shelter in American Culture (New York, 2001), 192.

8 "Boom to Bust," 20.

${ }^{9}$ See Elaine Tyler May, Homeward Bound: American Families in the Cold War Era (New York, 1988); Laura McEnaney, Civil Defense Begins at Home: Militarization Meets Everyday Life in the Fifties (Princeton, NJ, 2000); and Joseph Masco, The Nuclear Borderlands: The Manhattan Project in Post-Cold War New Mexico (Princeton, NJ, 2006). For studies of consumer culture in the Cold War, see Laura Belmonte, Selling the American Way: U.S. Propaganda and the Cold War (Philadelphia, 2008); Matthew W. Dunne, A Cold War State of Mind: Brainwashing and Postwar American Society (Amherst, MA, 2013); Thomas Doherty, Cold War, Cool Medium: Television, McCarthyism, and American Culture (New York, 2003); Lary May, ed., Recasting America: Culture and Politics in the Age of the Cold War (Chicago, 1989); Lynn Spigel, Make Room for TV: Television and the Family Ideal in Post-War America (Chicago, 1992); Walter L. Hixson, Parting the Curtain: Propaganda, Culture, and the Cold War 1945-61 (London, 1997); and Walter A. Friedman, Birth of a Salesman: The Transformation of Selling in America (Cambridge, MA, 2005).

${ }^{10}$ David Monteyne, Fallout Shelter: Designing for Civil Defense in the Cold War (Minneapolis, 2011).
} 
the inconsistent and personal ways private citizens engaged with the politics and practice of nuclear survival. ${ }^{11}$ A study of the home shelter market exposes the limitations of consumer capitalism in mobilizing popular support for national security policy agendas. In plying their trade, shelter businesses attempted to marry two eminently successful ideological constructs of the Cold War era: national security and the self-made, individualistic, suburban consumer family. But there were limits to even the best salesman's pitch. Over the course of an intense yet critical period in international tensions that culminated in the Cuban Missile Crisis, shelter salesmen became symbols of the absurdity of nuclear war, the impossibility of survival, and the opportunistic greed and ruthlessness that underpinned this particularly tasteless vision of Cold War capitalism. ${ }^{12}$ Given the opportunity to purchase their families' safety, most citizens actually rejected the salesmen's version of free market economics and questioned the value of private protection over communal survival. A consensus culture of consumption certainly greased the politics of national security, but Americans also engaged in heretofore overlooked forms of critical thought and social resistance.

Despite recent, nuanced histories about the local dimensions of the Cold War, scholars still tend to view civil defense as the failed project of national security, with the family fallout shelter a short-lived national obsession that declined with the easing of nuclear tensions and emergence of détente following the Cuban Missile Crisis. ${ }^{13}$ A study of shelter salesmen helps to explain why exactly a nation of home shelter builders failed to materialize. Typically, when historians discuss state efforts to turn "every home into a fortress" during the early Cold War, they mainly frame policies of do-it-yourself survival as being driven by state actors. ${ }^{14}$ But federal authorities were never alone in their efforts to encourage families to turn their basements and backyards into bomb shelters.

During the Cold War, the politics of home survival was defined by the rise of a new statebusiness nexus, which saw private companies try, often unsuccessfully, to provide a critical link between the intentions of the federal authorities to normalize preparations for nuclear war and the actions of homeowners. While the home fallout shelter was no doubt an "imagined design phenomenon"-both an artifact that brought the logic of national security into the home and a cultural idea advertised through state propaganda-family fallout shelters

\footnotetext{
${ }^{11}$ For discussions of the local Cold War, see Jeffrey A. Engel, ed., Local Consequences of the Global Cold War (Stanford, CA, 2008). For local histories of the nuclear state, see Gretchen Heefner, The Missile Next Door: The Minuteman in the American Heartland (Cambridge, MA, 2012); Kate Brown, Plutopia: Nuclear Families, Atomic Cities, and the Great Soviet and American Plutonium Disasters (Oxford, UK, 2013); Sarah Alisabeth Fox, Downwind: A People's History of the Nuclear West (Lincoln, NE, 2014); and Lindsey A. Freeman, The Atom Bomb in Me (Stanford, CA, 2019).

${ }^{12}$ Discussions of citizen-consumerism can be found in Lizabeth Cohen, A Consumers' Republic: The Politics of Mass Consumption in Post War America (New York, 2003); Sharon Zukin, Point of Purchase: How Shopping Changed American Culture (London, 2004); and Meg Jacobs, Pocketbook Politics: Economic Citizenship in Twentieth Century America (Princeton, NJ, 2005).

${ }^{13}$ A note on periodization of the shelter craze. Historians frame the shelter craze as "short-lived" and typically focus on the period between the Berlin Crisis in 1961 to the end of atmospheric testing in 1963. Dee Garrison's Bracing for Armageddon: Why Civil Defense Never Worked (Oxford, 2006), noted that these years represented the high point of national interest in the question of home shelter construction. Interestingly historians frame this period in terms of a national "craze," "obsession," or "panic." This view is supported by other prominent writers on national civil defense efforts, notably Margot A. Henriksen, Dr. Strangelove's America: Society and Culture in the Atomic Age (Berkeley, CA, 1997), who described civil defense in terms of the "intense months of the bomb shelter craze," 203; and Rose, One Nation Underground. Robert Jacobs, The Dragon's Tail: Americans Face the Atomic Age (Amherst, MA, 2010) argues that the end of atmospheric testing removed the visual presence of nuclear weapons from the American landscape and thus eased public concern over the question of survival.

${ }^{14}$ Guy Oakes, The Imaginary War: Civil Defense and American Cold War Culture (Oxford, UK, 1994); Andrew D. Grossman, Neither Dead Nor Red: Civil Defense and American Political Development During the Early Cold War (Oxford, UK, 2001); McEnaney, Civil Defense Begins at Home.
} 
were also consumer products, specified by the national security state and outsourced to private business interests looking to capitalize on government efforts to domesticate nuclear war. $^{15}$

The physical act of buying, building, and maintaining a family fallout shelter constituted a site of consumer exchange, not just an arena of public policy or a cultural talking point. At the apex of Cold War tensions, the politics and social practice of nuclear survival depended on the power of citizens as consumers to complete a transactional exchange and buy into the state-sponsored illusion that purchasing a shelter might bring survival in the next war. It is remarkable that the persistent failure of private businesses to create and sustain a marketplace for home shelters has not played a more prominent role in how historians have characterized the limitations of militarization. ${ }^{16}$ For Kenneth D. Rose, the reasons for public rejection of the home shelter were "complex"-a mixture of "fatalism, apathy and skepticism."17 But inconclusive hedges overlook the implications of public disdain for the consumer culture of home survival and its influence on the evolution of domestic nuclear security strategies. In the rise and fall of the shelter market, we might even observe a clear aversion to private and consumer-based actions as perceived solutions to geopolitical problems.

Sales, salesmanship, and the creation of profit were not afterthoughts in the development of civil defense; they were central to its social function. Asking homeowners how much they were willing to spend to ensure their families' survival, shelter businesses and their salesmen pressed forward a vision of consumer capitalism that tied the purchasing power of private citizens to their ability to partake in the Cold War. By encouraging homeowners to buy, construct, and furnish their own family bunkers, shelter salesmen made the attainment of private profit a central and controversial platform for civic participation in national security. Scholars have emphasized the efforts of Cold War policymakers to spread democratic capitalism both at home and abroad. ${ }^{18}$ But the story of shelter salesmen stands out as an anomaly. Frequently accused by their customers of profiteering, warmongering, and exploiting the fears of the vulnerable, shelter salesmen represented an unwanted addition to the Cold War marketplace and the "Consumers' Republic."19 Questioning the validity of the product being sold and the trustworthiness of the person pitching it, homeowners challenged the citizen-consumer ideal that supposedly went hand-in-hand with the state sanctioned vision of privatized survival.

\section{The Commercialization of Survival}

According to the Saturday Review, one of the shortest paths to wealth was the successful anticipation of a "national fad," and during the summer of 1961 the home fallout shelter stood to become one of the most "demanded consumer products" in Cold War America. ${ }^{20}$ As

\footnotetext{
${ }^{15}$ Sarah A. Lichtman, "Do-It-Yourself Security: Safety, Gender, and the Home Fallout Shelter in Cold War America," Journal of Design History 19, no, 1 (Mar. 2006): 39-55.

${ }^{16}$ See Jacobs, Dragon's Tail, 41.

${ }^{17}$ Rose, One Nation Underground, 220.

${ }^{18}$ Belmonte, Selling the American Way. For discussions of business, capitalism, and the Cold war, see Kenneth Osgood, Total Cold War: Eisenhower's Secret Propaganda Battle at Home and Abroad (Lawrence, KS, 2006); Reinhold Wagnleitner, Coca-Colonization and the Cold War: The Cultural Mission of the United States in Austria after the Second World War (Chapel Hill, NC, 1994); Nicole Woolsey Biggart, Charismatic Capitalism: Direct Selling Organizations in America (Chicago, 1989); Nelson Lichtenstein, State of the Union: A Century of American Labor (Princeton, NJ, 2002); Elizabeth Tandy Shermer, Sunbelt Capitalism: Phoenix and the Transformation of American Politics (Philadelphia, 2013); and Kevin M. Kruse, One Nation Under God: How Corporate America Invented Christian America (New York, 2015).

${ }^{19}$ Cohen, A Consumers' Republic.

${ }^{20}$ Norman Cousins, "Shelters, Survival, and Common Sense," part 4, Saturday Review 25, Nov. 15, $1961,31$.
} 
Kennedy's Berlin address ended, switchboards in local civil defense offices lit up. ${ }^{21}$ Phone lines that had received only the occasional call in preceding years quickly jammed as worried citizens tried to reach a voice of authority that might tell them exactly how to protect their families. ${ }^{22}$ For Frank Fields, a 42-year-old resident of Jacksonville, Florida, the impact of the President's televised address was immediate: "I had a sinking realization of what building a shelter was going to cost." ${ }^{23}$ In living rooms and across dining room tables, families discussed household finances and made swift calculations. ${ }^{24}$ As Kennedy gathered his advisors in the Oval Office to debate the nuances of nuclear diplomacy, a parallel story developed in towns and shopping malls across the United States. Stepping into a potent mixture of public demand for information and overwhelmed civil defense officials, local businessmen rebranded themselves as "survival specialists" and set out to persuade potential customers of the affordability of survival.

To be sure, the business of buying and selling survival predated 1961. From the establishment of the Federal Civil Defense Administration (FCDA) in 1951, commercial interests have played a prominent role in the practice of domestic security. ${ }^{25} \mathrm{~J}$. R. Sanchez, from New York, became perhaps the home survival industry's first pioneer when he decided in 1954 to open the door to his own company: LYN shelters. Sanchez never mentioned what inspired his new business venture, but he did make it abundantly clear what an "entrepreneur from New York can bring to the table." In a remarkable flurry of correspondence written to his local civil defense board, Sanchez maintained that his unique contribution to the Cold War was his background and "experience in retail ... people trust what I am selling. I always make commission." Sanchez actively sought to forge a partnership with FCDA authorities, claiming that what they truly needed was "good salesmen ... accurate and eager." ${ }^{26}$ Sanchez's letters reflected a concern that grew even more pronounced over the next few years-that the key to selling survival resided in the authenticity of the message. "I can present 'the survival story," Sanchez noted, "in its true dramatic manner ... my job, plain and simple, is to help make this a personal experience." ${ }^{27}$ Traveling through New York State with his "all-Aluminum trailer," LYN shelters were "happily endorsed" by federal authorities, with the director of the FCDA Val Peterson noting that Sanchez and his shelters were "the perfect mobile vehicle for educating the public about the ease of home survival." ${ }^{28}$ Each model came as a "completely selfcontained unit, including its own gasoline operated electric generator, Public Address System, and all important reception area for guests." LYN shelters simplified the message of domestic survival by creating a mobile product, "geared," in the words of Sanchez, to "illustrate just how simple survival really is for the average Joe out there!" ${ }^{29}$

\footnotetext{
${ }^{21}$ Reports from regional branches recall a sharp and quickly overwhelming number of requests for information and specifically copies of the 1960 Family Fallout Shelter construction manual. See Office Record of the Defense Preparedness Agency, OCD, NARA II.

${ }^{22}$ Alice L. George, Awaiting Armageddon: How Americans Faced the Cuban Missile Crisis (Chapel Hill, NC, 2003), 59.

${ }^{23}$ Frank Fields, Nov. 10, 1961, box 1, Subject File: Correspondence Cards, Public Affairs Office Record of the Defense Preparedness Agency, OCD, NARA II.

${ }^{24}$ Letters and correspondence cards addressed to the Kennedy White House, the OCD, and local papers frequently dwelled on the financial implications of shelter construction. Take for example Fred Hunt, who wrote to his local paper discussing in length the argument he had with his wife over the fact that buying or financing a shelter might mean not purchasing a new television. This sort of commodity balancing between "survival" and "luxury" informed the actions of shelter salesmen. See Sarasota News, Oct. 5, 1961, 56.

${ }^{25}$ McEnaney, Civil Defense Begins at Home, 40.

${ }^{26}$ Letter from J. R. Sanchez, May 4, 1954, box 2, Federal Civil Defense Administration (FCDA) Publications, 1950-1960, Records of the Office of Emergency Preparedness, RG395, NARA II, 1.

${ }^{27}$ Letter from J. R. Sanchez to Val Peterson, Aug. 17, 1956, folder 4, box 2, Val Peterson Executive Correspondence, Aug.-Sept. 1956, Records of the FCDA, RG395, NARA II.

${ }^{28}$ Letter from J. Val Peterson to J. R. Sanchez, Aug. 23, 1956, folder 4, box 2, Val Peterson Executive Correspondence, Aug.-Sept. 1956, Records of the FCDA, RG395, NARA II.

${ }^{29}$ Ibid., folder 4.
} 
From 1958 to 1961, a steady stream of commercial actors and small-scale promoters followed in Sanchez's footsteps. Under President Eisenhower's watch, the FCDA, now rebranded as the Office of Civil and Defense and Mobilization (OCDM), set out to strike a balance between fiscal responsibilities and national anxiety following the surprise launch of Sputnik in 1957 by steering civil defense efforts away from public projects and toward do-it-yourself survival. ${ }^{30}$ Advertising the family shelter as "the quintessential home improvement exercise," the OCDM turned toward small-scale promoters to market a vision of home survival. ${ }^{31}$ Over the next three years, the OCDM produced a steady stream of pamphlets, posters, and public exhibitions, all aimed at selling do-it-yourself survival. ${ }^{32}$ While the practice of home shelter construction remained decidedly imperfect, with a host of technical questions left unanswered, the OCDM put forth a strikingly coherent message-that homes and families with private shelters had a better chance of surviving the next war than those without them.

Contractors, manufacturers, promoters, and trade associations worked with federal civil defense officials from 1958 to 1961. Policymakers teamed up with industrial suppliers, manufacturers, and designers in a network that slowly commercialized the family shelter and oversaw a flow of materials, shelter blueprints, capital, and experience. While the variety and scope of the commercial network of civil defense varied depending on the region, the basic relationship among industrial suppliers, designers, and promoters remained unchanged. At the massmanufacturing stage of the product, federal authorities worked closely with a number of leading trade associations, ranging from the American Concrete Pipe Association (ACPS) to the National Lumber Manufacturers Association (NLMA) and Asbestos Cement Product Association (ACPA). ${ }^{33}$ These trade associations developed a strong collaborative partnership with civil defense officials and with defense architects working for the American Institute of Architects (AIA) to design model fallout shelters approved for franchise to regional dealers. ${ }^{34}$

Often supplied with local materials and assisted by local intermediaries, manufacturing companies and OCDM officials invested in the standardization of their product, in turn creating small regional monopolies. For example, the steel needed to build the seventy-three prefabricated walls that made up the Kelsey Hayes's home shelter was supplied by Armco Steel in Ohio working with American Iron and Steel Association (AISA), and finally sold by a regional supplier, James Byrne of Michigan, who staked a claim over Kelsey Hayes's sales in Oakland County. ${ }^{35}$ Families looking to buy a Kelsey Hayes shelter might then approach a local savings firm for financing options. ${ }^{36}$ Product control and cooperation between political and capital

\footnotetext{
${ }^{30}$ Reaction to the Soviet Satellite-A Preliminary Evaluation, box 35, White House Office of Staff Research, Special Project: Sputnik, Missiles, and Related Matters and Summary of Discussion, 339th Meeting of the National Security Council Oct. 10, 1957 concerning "Implications of the Soviet Earth Satellite for U.S. Security" and "Intercontinental Ballistic Missile (ICBM) and Intermediate Range Ballistic Missiles (IRBM) Programs," Oct. 11, 1957, DDE Papers of the President, NSC Series, box 9, 339th Meeting of the NSC, NARA II.

${ }^{31}$ For the complete discussion of Civil Defense and FHA loans, see Civil Defense: General, 1961: Jan.-Mar., National Security Files, Papers of the President, John F. Kennedy Library, Boston, MA [hereafter JFKL].

${ }^{32}$ Andrew Grossman has estimated that during the 1950s alone, 503 million pieces of civil defense literature aimed at embedding a doctrine of "self-help" at both the community and national level. See Grossman, Neither Dead nor Red, 157.

${ }^{33}$ Trade associations working with the OCD were printed on the back cover of civil defense pamphlets and shelter construction booklets. See Fallout Protection: What to Know and Do About Nuclear Attack (Washington, DC, Dec. 1961).

${ }^{34}$ The joint authored Department of Defense and OCD booklet Family Shelter Design (Washington, DC, 1961) lists eight shelter designs, with each linked to a specific material provided by one of the endorsed trade associations. The Belowground New Construction Clay Masonry Shelter was designed and built with materials from the National Concrete Masonry Association.

35"Family in the Shelter, Snug, Equipped and Well Organized," Life Magazine, Sept. 15, 1961, 105. Details on Armco Steel can be found in box 1, Subject 1960-1961, Public Affairs Office, NARA II.

${ }^{36}$ The FHA proposed that those wanting to apply for supported finance to build their shelter might do so in three ways. First, for the more intrepid shelter builders looking for "comprehensive rehabilitation" of existing
} 
interest integrated civil defense into the grassroots, as private consumption and homeownership combined with patriotism, market trust, and federal control to turn survival into a domestic commodity (Figure 1). ${ }^{37}$

Faith in shelters as a product initially accompanied consumer confidence in the credibility of local promoters. While federal officials working with the AIA specified the product and trade associations provided the material, shelter salesmen added what Newsweek described as "part showbiz, part peep show and hard sell" to the message of do-it-yourself survival. ${ }^{38}$ Just as the national pattern of nuclear survival filtered responsibility away from the state and onto the shoulders of the suburban family, a similar pattern emerged within the consumer politics of civil defense. If it was the civic duty of families to purchase and construct shelters, it followed that the salesmen needed to match the product to the needs and wants of their customers.

Salesmen, and the sales techniques they deployed, acted as the final step in a long process that had originated in the offices of civil defense planners then traveled down through trade associations, industrial suppliers, local financial institutions, and finally into the hands of small-scale promoters. Kelsey Hayes, for example, a wheel and brake manufacturer and now shelter seller, frequently cited itself in local marketing campaigns as "reputable," primarily by proudly claiming that its shelters were "OCD Approved," "FHA financed," "can withstand a house collapsing," and had been "featured in Life." 39 To ensure the "quality" of its product, Kelsey Hayes strictly controlled who might be able to make a profit out of its franchises. Local sales agents were interviewed by Hayes and tested on their "experience and credit rating" before being permitted to obtain a regional dealership. ${ }^{40}$ So close was the dependency of policy makers on private businesses that OCDM officials happily endorsed an ad from a Baltimore-based Formstone Company that told customers to "call your local civil defense office or us for all the details on how to survive an atomic attack." 41 The collaboration between policy makers, trade associations, and small-scale prompters created a marketplace in which economic exchange, capital growth, and potential profit was overseen by federal authorities at almost every step, with the aim of accruing credibility in the home shelter program (Figure 2).

Federal authorities also facilitated loans. The month after Kennedy's July Berlin address, the Federal Housing Administration (FHA) offered financing options for home shelters, allowing families to refinance their homes for shelters costing up to $\$ 10,000 .{ }^{42}$ In September, a highly publicized issue of Life dedicated to the family fallout shelter opened with a letter from

homes, sections $203(\mathrm{k})$ and $200(\mathrm{~h})$ of the home loan program now offered a path toward family survival. Projects that qualified for the 203(k) and 200(h) financing often fell under "substantial home improvement task," applied to dilapidated homes that needed foundation work, or if extensive remodeling was required. The scale of the task meant that blueprints of the planned construction work were to be provided ahead of time and inspection from the FHA once the site was complete. The second option was "refinancing their home through existing FHA mortgages" to pay for a shelter. The third option was for families to look to Title I of the property improvement loan, with domestic fallout shelters falling under "home improvement," with shelters framed as "dual purpose" rooms that might double up with the expansion into a new room. U.S. Congress, House of Representatives, Hearings Before a Subcommittee of the Committee on Government Operations, 87 Cong. 2nd sess., part II, Appendixes Committee on Government Operations, 1962, 366.

37 "Boom to Bust," 20.

38“Civil Defense: Who'd Survive," Newsweek, Aug. 7, 1961, 48.

${ }^{39}$ Kelsey Hayes advertisements can be found in local papers during 1961 and 1962, and were often limited to stories of new franchises that were modeling shelters. See The Daily Journal (Vineland, NJ), Oct. 26, 1961, 15; Democrat and Chronicle (Rochester, NY), Oct. 15, 1961, 85; Detroit Free Press, Oct. 8, 1961, 42.

${ }^{40}$ Advertisement in Pensacola News, Apr. 30, 1961, 16.

${ }^{41}$ Advertisement in The Evening Sun (Baltimore), Aug. 31, 1961, 45.

${ }^{42}$ Home loans were not actually funded directly by the FHA, but instead guaranteed to be repaid if borrowers defaulted. For full details of the FHA loans (including the changing regulations between 1961 and 1962 and rules for the inclusion of shelter improvements), see U.S. Congress, House of Representatives, Civil Defense, 1962: Hearings Before a Subcommittee of the Committee on Government Operations, Part II, Appendixes Committee on Government Operations, 87 Cong. 2nd sess., May 2, 7, 8, 10, and 16, 1962, 366. Local newspapers also often 


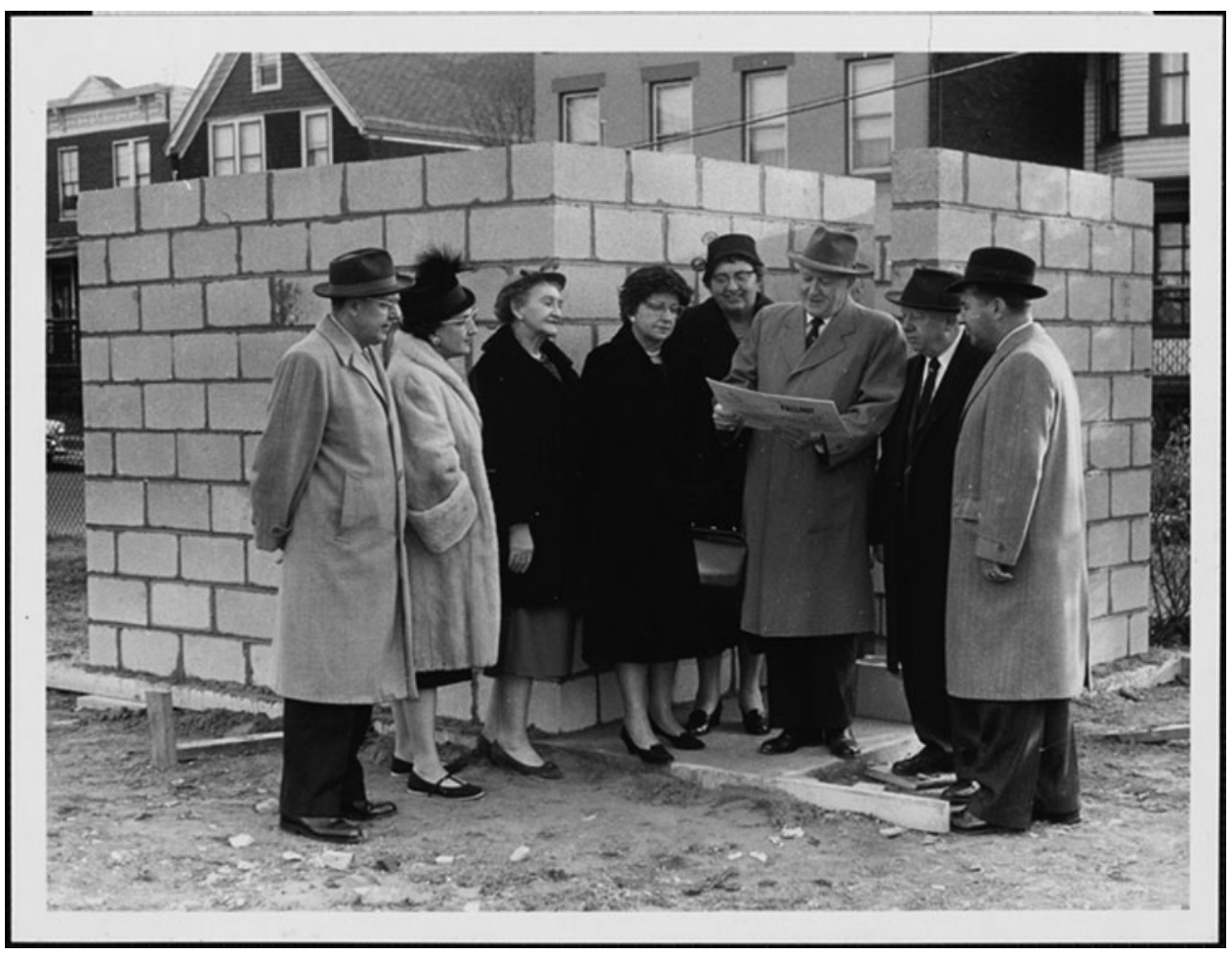

Figure 1. A prototype basement shelter in Bayonne, New Jersey. Civil Defense Photographs, 1951-1961, RG 304, Records of the Office of Civil and Defense Mobilization, 1947-1962, NARA.

President Kennedy and contained a full page advertisement for a Kelsey Hayes shelter. ${ }^{43}$ Expectations for the newly emerging home shelter market ran high, with one Congressional leader going as far as to predict that shelter manufacturers and sellers alike were soon to "achieve the magnitude and respect" of other federally promoted programs such as "highway building and urban renewal." ${ }^{4}$

Yet, steadily over the course of the next two years, officials lost control over the market they had created. Local contractors, construction firms, real estate companies, and even car dealers swiftly rebranded their existing businesses and opened new branches dedicated to selling survival. ${ }^{45}$ From July to December of 1961 , the number of OCD-approved regional civil defense distributions selling shelter franchises increased from 51 to $351 .{ }^{46}$ Yet the number of firms listed by OCD records, as operating under the guise of survival specialists, reached well into the thousands. In California, the newly branded construction company Nuclear Survival Corporation opened its doors to patrons in July of 1961 without any federal oversight, shortly followed in the same week by Peace-O-Mind Shelter Corporation in Texas, Survival-All Incorporated in Ohio, Survival Construction Specialist in Denver, and Diamond Blocks in Boston. ${ }^{47}$ In New

carried the details of FHA regulations and financing options: see HUD Aids for Fallout Shelter, U.S Department of Housing and Urban Development, vol. 59, 1962, Washington, DC.

43"Family in the Shelter," 105.

${ }^{44}$ U.S. Congress, House of Representatives, Subcommittee on the Committee on Government Operations, Civil Defense, 86 Cong. 2nd sess., May 2, 7, 8, 10, and 16, 1962, 20.

${ }^{45}$ Popular Mechanics, Oct. 1961, 32; Business History, Sept. 1961, 34; California Highways and Public Works, Nov. 1961, 45; Consumer Reports, 1961 and 1962, 7.

46"Shelter Sales," The Morning Call (Allentown, PA), Dec. 24, 1961, 79.

${ }^{47}$ Briefing Papers Steuart Pittman, June 9, 1961, folder 4, box 1, Central Files 1961-1968, FTC 3 Record of the Defense Preparedness Agency, OCD, RG398, JFKL. 


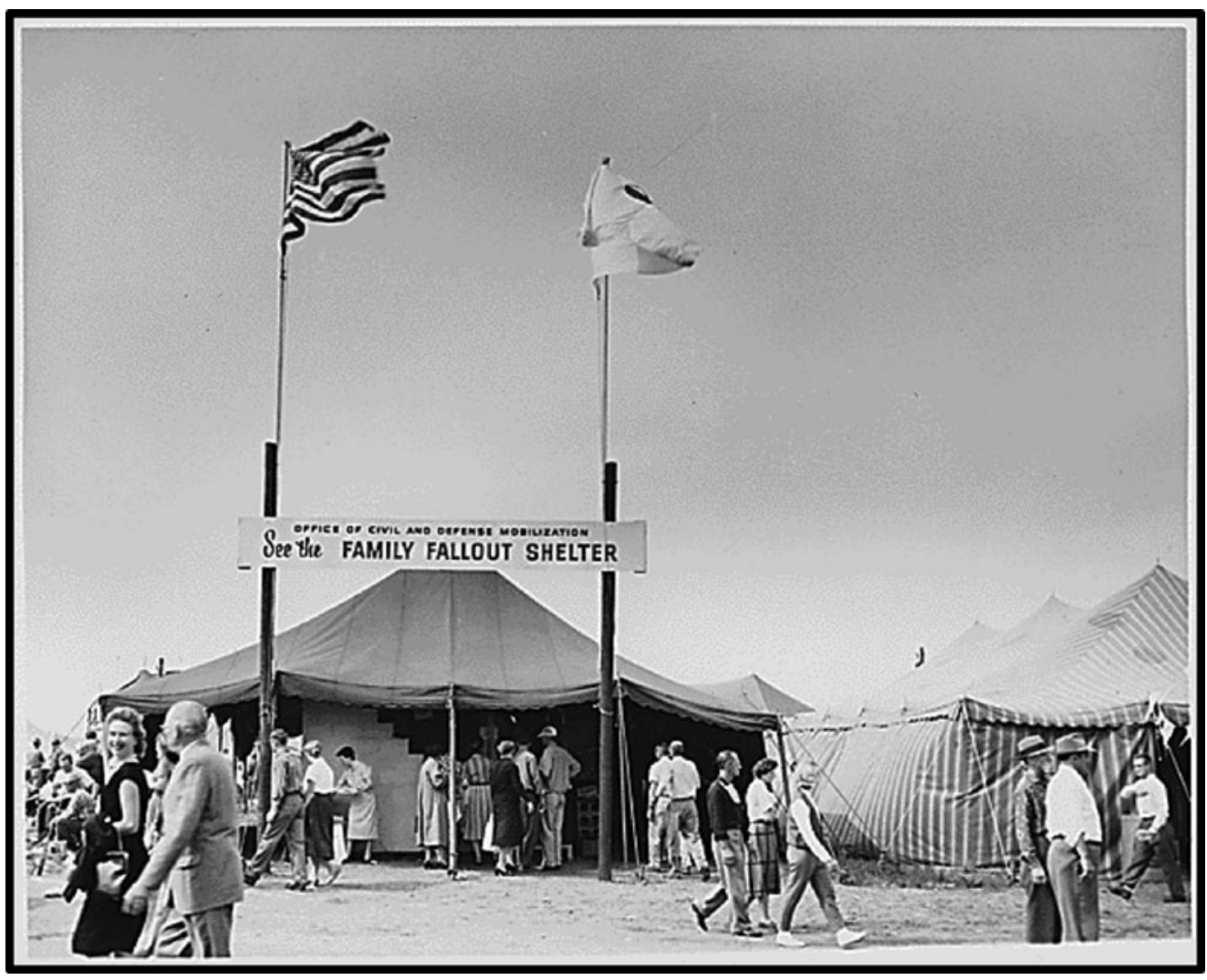

Figure 2. Office of Civil and Defense Mobilization exhibit at a local civil defense fair, 1960. Photographs of Civil Defense Personnel and Activities, RG 311, Records of the Federal Emergency Management Agency, 1956-2008, NARA.

Jersey, the Attorney General David Furman issued a statement warning residents to stay "vigilant against the sudden influx of 'fly-by nighters,' seeking to exploit the current situation." 48 Furman had a point. In Atlanta, Newsweek reported that during the first week in September 1961, "thirty shelter firms had been created" with "three small advertisements in local papers resulting in five thousand inquires." ${ }^{49}$ None of these new firms was OCD approved.

As these small-scale local promoters retrofitted trade practices and sold products far outside of OCD-approved specifications, the buying and selling of survival escalated out of state control. While sections of these rebranded businesses did seek federal approval for their new ranges of home shelters, others went about designing and displaying their own model shelters, which bore little resemblance to OCD regulations. ${ }^{50}$ In Las Vegas, the swimming pool company Vegas Pools decided to rebrand itself as the Fox Hole Shelter Company in November of 1961, and simply flipped an old swimming pool design upside down, claiming it was a shelter. ${ }^{51}$ Michigan's "most successful home realtor" opened its doors to a brand new Fallout Division in October, writing to local OCD officials for approval for shelter designs that bore little resemblance to the trade-association-sanctioned models. ${ }^{52}$

\footnotetext{
48"Shelter Held Likely," The Courier News, Oct. 3, 1961, 8.

49"“Must We Dig?” Newsweek, Oct. 14, 1961, 24.

${ }^{50}$ In 1961 the Office of Civilian Defense and Mobilization was reformed into the Office of Civil Defense (OCD).

51 "Re: Ellis, Frank Consultations," Apr. 5, 1961, box 3, Central HQ Operational Files, Publicity Record of the Defense Preparedness Agency, OCD, RG396, NARA II, 2.

${ }^{52}$ The Morning Call, Nov. 10, 1961, 13.
} 
In Philadelphia, one customer complained to authorities that the shelter he had been sold, and partially built before noticing the mistake, had been designed without any ventilation or air filter. ${ }^{53}$ In Portland, building regulations meant all structures needed to have windows installed, rendering OCD guidelines moot and leaving customers to contemplate the wisdom of a local salesman pitching them a model shelter with a "window through which to watch the mushroom cloud." ${ }^{54}$ In Southern California, one local manufacturer went as far as to offer a shelter that doubled as a space of fun and relaxation and claimed, incorrectly, that it was OCD approved. The shelter in question made a unique design choice of dividing the shelter into two sections: one half a swimming pool and the second half a fallout shelter with a "glass window to take pictures of the swimmers." While we can question how effectively the swim survival setup may have worked, the advertisement made it clear that any homeowner now had a space suitable "if the weather, or the war, gets hot." 55

\section{Enter the Survival Merchants}

The rise of shelter companies working outside of OCD control invites the question: who exactly were these new survival specialists? The records of private businesses, federal correspondences, and regional records of the OCD suggest that no "typical" shelter salesman existed. Experience, background, and business careers before and after the shelter craze varied greatly. But a few overarching patterns did structure what compelled individuals to join the ranks of the new survival merchants.

Despite popular perceptions, not all shelter businesses and salesmen were out to make a quick buck. Letters written to local OCD offices, often from those companies representing OCD-and trade association-approved regional suppliers, speak of a more complex drive to sell fallout shelters that included both profit and a sense of "community service." "It has not happened yet," recalled Indiana-based shelter salesman Evan Rosenbaum, "but we have all reason to believe it might. The President takes survival seriously and so do we." Working on behalf of the National Concrete Masonry Association (NCMA) as a self-described "reliable and reputable" home builder, Rosenbaum opened the doors of Atlas Shelters in September of 1961 for Indianapolis residents. By purchasing his skills as an "expert builder for $\$ 1000$," residents could support a local business and ensure their family's safety with someone they could trust. ${ }^{56}$

For a brief time, Rosenbaum and his Atlas Shelters functioned as a focal point for civic engagement with the local Cold War. Every successful shelter built was meticulously covered in the Indianapolis Star as Rosenbaum became a small-town human-interest story. ${ }^{57}$ Rosenbaum was not alone in his belief that selling shelters offered his local community a vital service. Frank Hopkins, a one-time plywood seller and now a fully fledged Sacramento shelter salesman, noted in a 1961 letter to President Kennedy that he was "proud to offer his neighbors the opportunity to survive the next war." Without an apparent sense of irony, Hopkins expressed his thanks to the president for offering his local business a chance to "help folks around here stand up to the Soviet Union." For Hopkins, the decision to refashion his skills from car dealer to shelter salesman contributed to the survival of the nation he "love [d] dearly." 58

\footnotetext{
${ }^{53}$ Unknown author, "Shelters and Vulnerability Reduction Sept.-Oct.," July 4, 1961, box 24, Central Files 19611968, Record of the Defense Preparedness Agency, OCD, RG397, NARA II, 4.

${ }^{54}$ The Guard (Eugene, OR), Oct. 12, 1961, 8.

${ }^{55}$ Post Herald (Beckley, WV), July 15, 1962, 40.

${ }^{56}$ Evan Rosenbaum to OCD, Oct. 3, 1961, "Shelters and Vulnerability Reduction Sept.-Oct.," box 24, Central Files 1961-1968, Record of the Defense Preparedness Agency, OCD, RG397, NARA II, 1-2.

57"Local Shelters Go on Sale," Indianapolis Star, Oct. 24, 1961, 67.

${ }^{58}$ Frank Hopkins, Nov. 13, 1961, folder 14, box 24, Central Files 1961-1968, Record of the Defense Preparedness Agency, OCD, RG397, NARA II.
} 
Local promoters chose how their shelters were advertised, pitched, and priced. While Hopkins and Rosenbaum decided to sell their products out of a desire to protect their communities, far more common are accounts of individual salesmen responding to advertisements in local papers claiming that in the age of nuclear war selling shelters was "a real money maker." ${ }^{\text {" Ap }}$ Apearing frequently in the pages of local business sections of newspapers during 1961 and 1962, help wanted advertisements called for individuals who had the ability to "close deals" to join their ranks and take part in the anticipated shelter boom. ${ }^{60}$ With the promise of high commission, training in the basics of atomic science, and the chance to get in at the ground level of an "exciting" new market, these want-ads clearly advanced profit over anxiety or service. In November of 1961, Jason Olson of Pennsylvania Avenue, Minneapolis, who had recently opened a new Fallout Division of his real estate company, advertised an "outstanding opportunity to well groomed, experienced men of proven ability to sell America's finest shelter." ${ }^{61}$ It is not clear whether Olson managed to hire his well-groomed men, but he certainly set out to appeal to the commercial interests of his applicants. In Boston, General Survival Corporation informed interested parties that life as a shelter salesman offered "unlimited profits and exclusive regional coverage." ${ }^{62}$ In Chicago, the Protect-All shelter company asked for "ambitious and assertive salesmen looking for high commission" to join their ranks. ${ }^{63}$

Obtaining a high commission and fulfilling the promise of "unlimited profits" required shelter salesmen to stimulate consumer demand for the products they sold. While the sales pitch often failed, the efforts of sellers to maneuver homeowners into making a financial commitment to home survival required the development of sales strategies that overcame the doubt and dismissal of the buyers they encountered. As such, shelter salesmen developed sales techniques and local marketing campaigns that informed potential buyers about the function of shelters to persuade them that their products were of a high quality, and in some cases, even luxurious.

Early 1950s civil defense literature had framed the act of building a shelter as a quasimilitary function for the post-war family-a way to actively participate on the home front as both soldiers and civilians. At the height of the shelter craze, however, salesmen adopted a new tactic in their advertisements. They softened the rhetoric of survival by actively pitching the act of shelter construction not simply as an act of protection but as a task in which any family wishing to improve their home might participate. "You are building a shelter and you are building a hobby room!" shelter salesman Thomas Edwards wrote in the Kansas City Star in 1959. ${ }^{64}$ This sentiment was echoed by the American Institute of Decorators (AID) in its three-page advertisement, "designing for defiance," in 1960. According to these ads, the construction of a "fallout shelter is not just about doing all you can to protect your family"; the act of building a family shelter was a "home improvement exercise" that also provided a room that might "double as an extra activity area for fun and relaxation." The family fallout shelter was not solely a nuclear bunker, but was also for "daily use" as a "hobby room, music room, or recreation room." ${ }^{65}$ Shelter advertisements made the remarkable claim that the act of family protection constituted an experience that homeowners might enjoy. As one Wisconsin-based

\footnotetext{
59"Salesmen: To Sell Fallout Shelters," The Cincinnati Enquirer, Oct. 30, 1961, 40.

${ }^{60}$ Los Angeles Times, Nov. 7, 1961, 56; The Tennessean, Oct. 30, 1961, 22; Fort Lauderdale News, Nov. 28, 1961, 22.

${ }^{61}$ Star Tribune, Nov. 10, 1961, 29.

${ }^{62}$ Boston Globe, Sept. 4, 1961, 72.

${ }^{63}$ Chicago Tribune, Oct. 8, 1961, 90.

64"Shelter Sale," Kansas City Star, Mar. 5, 1962, 13.

${ }^{65}$ American Institute of Decorators collected, folder 3, box 2, Public Affairs Office Subject 1958-60, Record of the Defense Preparedness Agency, OCD, RG396, NARA II.
} 
shelter tradesman quipped in 1961, shelter owners will be able to "bring the buddies round ... play some hands of poker ... show off to the neighbors." ${ }^{\prime 66}$

The homeowner who bought a fallout shelter was not just a good citizen but also fulfilled a personal desire to consume, to make the domestic space more appealing, and to affirm his patriotism through the act of safeguarding his family. ${ }^{67}$ As one salesman stated during the 1961 Chicago Home Furnishing Market exhibit, personal shelters allowed homeowners to "battle the commies" while also "waiting out radiation danger in pleasure and comfort, and relaxation." In the words of a Michigan-based designer and seller of home survival products, "why shouldn't the end of the world be comfortable?"68

The sales training received before hitting the road also informed the art of selling survival. Training varied with the companies, with those working for trade associations frequently engaging with civil defense booklets and educational material while other companies felt free to take more of a creative license by curating their own training material. Common practice, however, included the use of printed photographic slides depicting various shelter models that needed to be studied and flip cards with key facts about shelter price points to be memorized. ${ }^{69}$ Shelter flip cards, collected in part by local OCD officials, often contained memorable sayings from politicians and key statistics on the likelihood of survival-drawn from the pages of popular magazines or fabricated by the salesmen. Sales pitches contained a staggering amount of misinformation. "Make no mistake! Family Fallout Protection is a serious business," claimed one Pennsylvania-based Family Fallout Shelters Inc. "Make sure you investigate the facts before you buy and get the facts from us!" The facts in question, which included a model shelter made almost entirely from plywood, demonstrates quite clearly just how tenuously the facts might be stretched to secure a sale. ${ }^{70}$

Sales brochures, the primary prop carried by hand for doorway interactions, also provided the basis for sales pitches. Howard Shaw, founder of Survive-All Shelters of Columbus, Ohio, provided his salesmen with a booklet he had produced in partnership with the Mort Kridel Advertising Agency. The brochure for Survive-All Shelters included a mixture of cultural and political references to create a common ground for sales interaction. A film still from On the Beach (1959) appeared alongside discussions of presidential support for home shelters in Life and quotations from prominent supporters of civil defense, notably New York Governor Nelson Rockefeller and father of the hydrogen bomb Edward Teller. As the booklet attempted to render the act of purchasing a shelter both familiar and relatable, it also reminded the salesman that the "customer must not be afraid to confront the issue at hand."

Price also played a role in the sales negotiation. Typically, shelters cost anywhere from the suspiciously low $\$ 150$ to the tens of thousands of dollars for a multiple, deluxe-room shelter complex. ${ }^{72}$ Price gave salesmen the option to upsell their product. Survival All and Shelter

\footnotetext{
${ }^{66}$ Quoted in a memo to Steuart Pittman, Nov. 10, 1961, box 1, Accounting and Finance, Central Files 19611968, Record of the Defense Preparedness Agency, OCD, RG397, NARA II.

67"You Can Build a Low-Cost Shelter Quickly," Popular Mechanics, Dec. 1961, 85-9. Popular Mechanics provided guidelines on outdoor and indoor shelter construction in addition to instructions on how to maintain shelter air filters and antennas.

${ }^{68}$ Mark Finn to OCD, Oct. 9, 1961, Shelters and Vulnerability Reduction, Sept.-Oct., box 24, Central Files 19611968, Record of the Defense Preparedness Agency, OCD, RG397, NARA II.

69"Request for Interview," Nov. 10, 1961, box 3, Subject File: Correspondence Cards, Public Affairs Office Record of the Defense Preparedness Agency, Office of Civil Defense, RG397 NARA II, 2; "Salesmen in Training" Request for Booklet Fallout Protection: What to Know and Do About Nuclear Attack," Oct. 3, 1962, box 3, Subject File: Correspondence Cards, Public Affairs Office Record of the Defense Preparedness Agency, OCD, RG397, NARA II.

${ }^{70}$ The Mercury (Pottstown, PA), Oct. 14, 1961, 20.

${ }^{71}$ Survive-All Shelters have been discussed on the Conelrad website and can be found in box 2, "Information and Public 1960-1961," Record of the Defense Preparedness Agency, OCD, RG397, NARA II.

${ }^{72}$ Price points varied greatly for shelters. For example, in an article "Fallout Shelters for Sale-Cheap," The Anniston Star (Apr. 12, 1962, 24) listed a model for $\$ 150$ that provided basic materials for self-assembly, while the Morning Herald (July 25, 1962, 33) spoke of luxury models ranging well into the $\$ 10,000$ s.
} 
Inc. sales brochures displayed a range of options from "basic models" that claimed to offer all the "necessities of survival," to luxury models that were spacious, equipped with rugs, or boasted "expensive indoor paneling." Ambley noted that if his buyers balked at the initial cost of purchasing a shelter, then a range of financing options and a "lowering of costs might be discussed if it meant closing a sale." If a customer agreed that a shelter was a necessary purchase, then it made sense to Ambley to encourage buyers to spend a little more to make their spaces as "impressive and comfortable as possible." "After all," Ambley noted, "war or not, it'll make a pretty dandy extra room at a price you can afford." ${ }^{74}$ These pitches, designed to overcome buyer reluctance, started a dialogue between salesmen and customers over the practicality of survival. But as shelter salesmen went about knocking on doors and setting up displays, they soon found themselves facing a backlash.

\section{The Struggle to Sell Survival}

According to Consumer Reports, a total of 200,000 home fallout shelter assembly kits sold between 1961 and $1962 .{ }^{75}$ This figure can be questioned, considering the reported incidents of homeowners keeping shelters "secret" from both their neighbors and the authorities. ${ }^{76}$ Nevertheless, the estimated 200,000 shelter kits sold to a population of 180 million illustrates a fundamental truth about civil defense during the early Cold War, namely that most Americans, when faced with the opportunity to purchase, construct, and furnish their own shelters, declined to do so. For the analysts of Consumer Reports, the commercial failure of shelters came down to the product itself: "Fallout shelters of the type widely proposed to date," the director at Consumer Reports argued, are too "costly and complex in their requirements [oxygen supply, water, power, heat, food, sanitary arrangements] ... limited and unreliable in usefulness ... dependent on variants and unknowns."77 Yet, recorded testimonies of salesmen tell a more complex story of failed expectations, declining profits, and an American public trying to make sense of a federal policy that encouraged homeowners to take survival into their own hands.

The experience of shelter salesmen illustrates that American consumers rejected backyard bunkers for reasons other than quality and cost. Questions of class and race played a complex role in the story of the shelter salesmen. As a consumer commodity, home shelters were accessible only to those homeowners with spacious yards. The consumer culture of survival co-existed with housing policies that had for decades, through discriminatory lending and prejudicial real estate practices, structurally excluded non-white communities from equal access to the suburban housing market. For Robert Faust of Pittsburgh, buying a shelter "is luxury out of our reach."78 "One guy shouted at me-actually shouted," Steven Heck, a sales representative for Michigan-based Gricar-Anderson shelters recalled. Apparently Heck's potential customer had yelled, "Don't you know that the more shelters we have the more likely someone is

\footnotetext{
${ }^{73}$ Robert Ambley, Dec. 5, 1961, Shelters and Vulnerability Reduction, Nov.-Dec., box 24, Central Files 19611968, Record of the Defense Preparedness Agency, OCD, RG397, NARA II.

${ }^{74}$ Ibid.; advertisement also appeared in the Cincinnati Enquirer, July 22, 1962, 48.

75“"Enter the Survival Merchants," Consumer Reports 27, no.1 (Jan. 1962): 47. Details on how many shelters were constructed have long been difficult for historians to fully uncover, because shelters were kept secret, or only partial constructed, or else never recorded by the OCD. The most accurate reports therefore come from the FHA approval records for shelters that had been financed, inspected, and constructed. These figures range from around 950 in Sept., 1,224 in Oct., and 894 in Nov. 1961. See House Reports of the Congressional Serial Series of the United States: Public Documents (Washington, DC, 1962), 46.

${ }^{76}$ Arthur I. Waskow, "The Shelter Society: A Report of a Peace Research Institute Conference on Potential Implications of a National Civil Defense Program," Journal of Conflict Resolution 9, no. 3 (Sept. 1965): $397-412$.

${ }^{77}$ "Enter the Survival Merchants," 47.

78“Baldwin Couple Likes Neighbors," Pittsburgh Press, Oct. 1, 1961, 56.
} 
about to start a war? Why do you do this to us?"79 Far from being received with magnitude and respect, salesmen were often seen as an unwanted intrusion, exploiting private citizens and making a profit out of community fear.

The records of the shelter companies also suggest that the fallout firms did not suffer from a shortage of curious, and often ambivalent, patrons. James Cline, the manager of a lumber company in Royal Oak, Michigan, like many of the owners of newly emerging shelter companies in 1961, decided to turn his hand to selling survival after reading Life's fallout shelter special issue in September of 1961. Cline was struck by "the elegant design" and the "ease" with which Life's model shelter family, the Carlsons, had constructed their own shelter. With little technical or design experience of his own, Cline struck up a regional dealership with the Detroit-based Kelsey Hayes, the company whose model prefabricated steel shelter was featured heavily in Life. Constructing a Kelsey Hayes shelter in his lumberyard and advertising shelter assembly kits at $\$ 725$, Cline was initially shocked by the volume of people visiting his display. More than two thousand shoppers walked through, viewed, and discussed the home shelter display over an eight-week period. ${ }^{80}$ Yet he sold only one shelter. Not only did Cline face a commercial disaster, but he also stated that members of his own community in Royal Oak were far from happy with his new business venture. "People were confused, frightened, angry," Cline recalled. "I was accused of profiteering, war-mongering-you name it." For the people of Royal Oak, Cline represented the idea that nuclear war might come to their community and, more appallingly, that surviving the next war had a price tag. ${ }^{81}$

James Cline's experience was by no means unique. Recorded incidents of public disdain for shelter salesmen litter public testimonies. ${ }^{82}$ The varied and often hostile responses to shelter sales pitches reveal the contradictions of civil defense as a capitalist venture. In most social histories of the Cold War, the creation and maintenance of domestic spaces such as garages, workshops, and barbecue pits have typically been framed as a means to affirm conventional ideas of masculinity in an increasingly suburbanized world. ${ }^{83}$ American men, as Steven Gelber has argued, sought to forge "a domestic masculine identity" through do-it-yourself home activities that created a male space in the suburban home while simultaneously allowing men to "actively participate in family activities." ${ }^{84}$ However, in the case of the local experiences of fallout shelter salesmen, the narrative of domestic masculinity, dominant in the marketing culture of civil defense, becomes complicated and muddied. Rather than the man-of-action consumer that supposedly underpinned postwar masculinity, potential fallout shelter owners appear from public correspondence as confused, incompetent, and skeptical. ${ }^{85}$ John Boyd, a father from Oklahoma writing to the OCD in July of 1961, recalled his experience with a shelter salesman: "If I build a shelter, if it even works, then what? I ask the sales guy this very question. He just shrugged and told me 'better than doing nothing at all.' I didn't trust him; the whole thing left a bad taste in my mouth." 86 "Why would I take out a loan to bury my family underground?" Boston father Jake Willis commented when writing to the OCD in October of 1961, adding,

\footnotetext{
${ }^{79}$ Steven Heck to OCD, Nov. 10, 1961, box 1, Subject File: Correspondence Cards, Public Affairs Office, Record of the Defense Preparedness Agency, OCD, RG397, NARA II.

${ }^{80}$ Alfred Balk, “Anyone for Survival?” Saturday Evening Post, Mar. 27, 1965, 74.

${ }^{81}$ Cousins, "Shelter, Survival and Common Sense," 26.

${ }^{82}$ These records are stored in and among letters from shelter builders in "Shelters and Vulnerability Reduction Jan.-Mar.," boxes 1-12, Central Files 1961-1968, Records of the Defense Preparedness Agency, OCD, NARA II.

${ }^{83}$ See, for example, Michael Kimmel, Manhood in America: A Cultural History (Oxford, UK, 2005), 223-58, and Ralph LaRossa, The Modernization of Fatherhood: A Social and Political History (Chicago, 1997).

${ }^{84}$ Steven Gelber, "Do-It-Yourself: Constructing, Repairing, and Maintaining Domestic Masculinity," American Quarterly 49, no. 1 (Mar. 1997): 66-112, here 66.

${ }^{85}$ D. B. Holt and C. J. Thompson, "Man-of-Action Heroes: The Pursuit of Heroic Masculinity in Everyday Consumption," Journal of Consumer Research 31, no. 2 (2004): 425-40.

${ }^{86}$ John Boyd to OCD, July 30, 1961, Shelters and Vulnerability Reduction, Sept.-Dec., box 12, Central Files 1961-1968, Record of the Defense Preparedness Agency, OCD, RG397, NARA II.
} 
"What sort of father would do that?" ${ }^{87}$ Far from the affirmation of federal messages of domestic survival, the family shelter was, for many, a grim reminder of their vulnerability and impotence.

The narrative of Cline and potential customers such as Boyd and Willis suggest genuine public unease with the transaction of buying a shelter. The salesmen also encountered additional difficulties as they plied their trade. One of the most complete and detailed salesman accounts is from James Byrne, a Detroit-based plywood salesman, who also recalled the limitations of selling do-it-yourself survival. For Byrne, selling home shelters was something of a "can't miss proposition," with every political statement from the Oval Office and the magazine article in Life providing, in his own words, a "million-dollar free advertisement." 88 The potential profit margins also proved attractive. One Kelsey Hayes shelter kit, which came in seventythree prefabricated steel sections weighing in at around 150 pounds, could be purchased by Byrne at a wholesale price of $\$ 433$ and sold for a retail price of $\$ 725 .^{89}$ The representative from Kelsey Hayes was quick to point out that not only had the department store Sears, Roebuck and Company already "agreed to test-market" the product, but that a "national 'saturation' advertisement campaign" was in the works. ${ }^{90}$ The "quality" of the product could also be trusted. Byrne believed the sales agent, who assured him that the Kelsey Hayes brand of home shelter was easily built: "two men could assemble it in two to four hours." $\mathrm{On}$ paper, Kelsey Hayes shelters provided the perfect vehicle for Byrne to make a profit, perform a patriotic duty, and provide a DIY task any homeowner with basic manual skills and craftsmanship might complete.

Buying fourteen unassembled Kelsey Hayes shelter assembly kits, Byrne sold thirteen to other regional dealers in the state who, like himself, had seen an emerging opportunity in the home shelter market. Keeping one shelter back to act as a model display to attract buyers, Byrne placed a second order for another fourteen shelter kits. Eagerly anticipating the popularity of his new business venture, Byrne invested $\$ 20,000$ into a local advertising campaign, assigned two of his employees to construct one of the model shelters, and eagerly waited for customers. The first problem arrived when Byrne found his workmen struggling to put together the model shelter. Rather than taking the two hours claimed by the Kelsey Hayes representative, Byrne's team took ten. The second issue came once the walls were erected. Byrne, looking to reinforce the shelter walls to OCD specifications, which required "dumping a small mountain of sand-four to five cubic yards-into eight-inch hollows between the walls and ceiling panels," realized that the task would take an additional ten hours. Faced with a series of complications, Byrne started to doubt the validity of the Kelsey Hayes spokesman's claims. If Byrne and his workers struggled, how was an ordinary homeowner going to overcome these basic construction problems? "You will be filling a space nearly seven feet high, and there are only a few inches of clearance between the shelter and the basement ceiling ... how are you going to get the sand in there? With a spoon?"92

It is clear from Byrne's experience that the construction of a Kelsey Hayes fallout shelter went far beyond the realms of a typical DIY exercise. The physical act of construction, central to the advertisement of family shelters, was a persistent problem, with both salesmen and the public struggling to erect their own shelter kits. The failed craftsmanship of the family fallout shelter quickly negated the consumer message of do-it-yourself survival, creating in its place an almost comical narrative of families and salesmen trying and failing to build their own shelters. Public letters to the OCD during the week of the Cuban Missile Crisis brimmed with accounts

\footnotetext{
${ }^{87}$ Jake Willis to OCD, Nov. 1, 1961, Shelters and Vulnerability Reduction, Sept.-Dec., box 14, Central Files 1961-1968, Record of the Defense Preparedness Agency, OCD, RG497, NARA II.

${ }^{88}$ Balk, "Anyone for Survival?," 74.

${ }^{89}$ "Family in the Shelter," 10.

${ }^{90}$ Marcus Raskin to McGeorge Bundy, Oct.17, 1961, folder 3, box 295, Subject File Civil Defense, JFKL.

${ }^{91}$ Balk, “Anyone for Survival?," 75.

${ }^{92}$ Ibid., 75.
} 
of failed shelter construction projects. Issues that homeowners encountered ranged from water leaks, prefabricated walls not fitting in basements, collapsed shelter ceilings, and local authorities refusing planning permission. Some Miami residents complained that low-lying ground water had made the evacuation of basements almost impossible, while in Ohio a local farmer's attempt to build a shelter had led him to strike into a water pipe, flooding his home and creating a local water shortage. ${ }^{93}$ Narratives of failed DIY projects quickly supplanted the political ideal that suburban fathers, armed with a host of tools, a shelter construction kit, a sense of patriotic duty, and a set of instructions, might be able to provide a meaningful form of domestic security for their families. According to its new director Steuart Pittman, the OCD faced, at the height of the bomb shelter craze, "a national DIY disaster." 94

In the case of James Byrne, despite his personal misgivings, a substantial capital investment was already in place. Still convinced that shelters had the potential to turn a profit, Byrne assigned his best salesman, Sal Gorge, to recruit a team of door-to-door salesmen to start selling shelters to the suburbanites of Detroit, offering a $\$ 100$ commission for every sale made. They sold not a single shelter. "They went out with high hopes," Sal recalled. "They pointed out how shelters were useful not only as shelters, but also, when paneled, as a spare room, study or photo lab. They really wanted those $\$ 100$ commissions." 95 According to Sal, poor sales resulted from two factors. The first remained the cost of the shelter, with "we can't afford it now" or "we will see how things turn out in Berlin" featuring as common responses to his sales pitch. ${ }^{96}$ The second problem was the message of do-it-yourself survival: "People listen to the sales pitch, take all the literature" then "ask questions and then just walk away ... they just didn't buy it." ${ }^{97}$ Even during the Cuban Missile Crisis, the public still rejected Byrne's shelters. In October 1962, a day after Kennedy told the nation that missiles had been discovered in Cuba, Sal and Byrne decided to load up the back of a flatbed truck with the model shelter. In a last-ditch attempt to attract sales, the salesmen parked the model shelter in "parking lots, shopping centers and veteran halls," dropped the price by $\$ 100$, and posted a display sign reading "FALLOUT SHELTERS -WHILE THEY LAST." Despite a steady stream of foot traffic to the display, there was not even a "nibble of a sale": "That shelter was out there day and night unattended ... not so much as a bolt was stolen ... even vandals weren't interested." Eventually Byrne placed an advertisement offering shelters free of charge, which was taken up by a family in Westphal, Michigan, who took the shelter away. "Last I heard from them they were having trouble assembling it. But I'm not asking questions." 98

To be sure, a small subset of shelter companies did have limited success. For example, salesmen such as Frank Norton, Director of the National Shelter Association, and former OCDM director Leo Hoegh reported a profitable year in 1961, in large part owing to their pre-existing strong institutional contacts. Unlike individual salesmen such as James Byrne, certain shelter salesmen were in frequent correspondence, or had been in the past, with civil defense policy makers, and constantly worked through federal channels when plying their trade. ${ }^{99}$ The policy maker-turned-profiteer Leo Hoegh was able to keep his own company Wonder Inc. afloat by staying on the right side of administrative policy and public sentiment by moving from selling

\footnotetext{
93“Summary of Studies of Public Attitudes towards Civil Defense", Dec. 2, 1961, folder 14, box 2, Information and Public, Record of the Defense Preparedness Agency, OCD, RG396, NARA II, 14.

${ }^{94}$ Pittman to Regional OCD Directors, Dec. 18, 1961, box 6, Shelters and Vulnerability Reduction, Central Files 1961-1968, Record of the Defense Preparedness Agency, OCD, RG397, NARA II, 2.

${ }^{95}$ Balk, "Anyone for Survival?," 75.

${ }^{96}$ The public "ignoring" shelter sales pitches was a common feature in articles discussing the bomb shelter craze. See Walter Karp, "When Bunkers Last in Backyards Bloomed," American Heritage (Feb., 1980): 92.

${ }^{97}$ Balk, “Anyone for Survival?," 75.

${ }^{98}$ Ibid., 78.

${ }^{99}$ Regulations discussed in internal memo, Nov. 4, 1961, box 1, Executive Correspondence and Memo, Records of the Office of Emergency Preparedness (OEP), 1961-1963, RG398, NARA II.
} 
individual home shelters to constructing public work shelters in schools. Yet not every successful shelter company had such close institutional affiliations.

Despite the dominance of do-it-yourself rhetoric, those shelter companies that reported limited success did so by taking on the responsibility of home protection themselves. Indeed, the successful shelter companies made a profit not by selling construction kits for homeowners, but by offering their own services as building contractors who, for a fee, could cut out the middle man for the suburban middle-class homeowner and build fallout shelters for them. In place of an industry premised on homeowners building shelters, a new service industry developed by private contractors started to take hold. "For two years I've starved in this business," noted shelter salesman Douglas Batholow. However, "since Kennedy's defense talk," his Orlando-based company that offered private shelter construction, instead of simply DIY kits, had "averaged two sales a day at $\$ 2,195$." ${ }^{100}$ In contrast to construction kits, sales for shelter construction services at the tail end of 1961 appeared to be healthy. ${ }^{101}$ In Boston, one shelter contractor was "overwhelmed" with orders, and in October of 1961 turned down \$780 contracts from "panicky citizens" who asked him to build shelters "the next day."102 In Sacramento, Atlas Shelters and its $\$ 5,000$ to $\$ 6,000$ OCD-approved six-person capacity, 35-ton prefabricated shelters had proved so successful that little publicity was needed. According to the owner of Atlas Shelters, Frank Ringer, public interest in backyard excavation and shelter construction was such that "we haven't done any advertisement yet, there's so much demand we hardly keep up with it." 103

The narratives of shelter companies during the height of the bomb shelter craze speak of an infant industry, unregulated and out of control, struggling to translate the consumer language of do-it-yourself survival into direct sales by offering building services. However, the potential market growth in shelter building quickly became overshadowed by a new issue confronting potential buyers of home fallout shelters: claims that those shelter salesmen were steeped in fraudulent business practices. By the summer of 1962, honest shelter companies and salesmen working alongside OCD guidelines operated in what was critically discussed as a market run by "fly by night" salesmen, falsely "claiming to sell government approved shelters" operating alongside reputable firms. ${ }^{104}$ Consumer Reports declared that anyone from "swimming pool contractors to car dealers ... are claiming to be authorities on bomb shelters." ${ }^{105}$ Reports to the Federal Trade Commission (FTC) indicated that in Los Angeles, New York, and Chicago, shelter salesmen were "posing as civil defense officials" to boost faltering sales. ${ }^{106}$ By 1962, the biggest question faced by shelter companies across the United States was their own credibility.

\section{The Decline of the Shelter Salesmen}

By the start of 1962, reports of unscrupulous business practices had turned fallout shelter salesmen into a front-page headline. "No group of citizens," syndicated columnist James Reston wrote for the New York Times, "is showing more solicitude for the well-being of the nation" than those salesmen who decided to turn a profit out of national fear. For Reston, the existence of the fallout shelter salesmen exposed the inequality in the federal civil defense program-a

\footnotetext{
${ }^{100}$ Quoted in "Civil Defense: The Sheltered Life," Time, Oct. 20, 1961, 21-6.

101 "Boom to Bust," 20.

${ }^{102}$ Frank Ringer to OCD, Feb. 13, 1962, Subject File: Correspondence Cards, Public Affairs Office Record of the Defense Preparedness Agency, OCD, NARA II.

${ }^{103}$ Quoted in Allan M. Winkler, Life Under a Cloud: American Anxiety About the Atom (New York, 1993 ), 129.

${ }^{104}$ Steuart Pittman Oral History Interview- \#2, Mar. 5, 1983, John F. Kennedy Oral History Collection, JFKL.

105“Coffins or Shields," Time, Feb. 2, 1962, 15.

${ }^{106}$ Thomas Hagen to Pierre Salinger, Sept. 15, 1961, "ND2 Civil Defense," box 5, Subject Files Civil Defense, RG39, NARA II, 2.
} 
government policy that seemingly offered survival to the few who could afford it, favoring "the rich over the poor, the single house dweller over the apartment dweller, the homeowner over the renter." ${ }^{107}$ Rather than providing a public service, shelter salesmen merely offered the gullible homeowner a chance to be "evaporated in style." 108 Reston was not alone in his critique of the commercialization of civil defense. William L. Shirer, writing for Good Housekeeping, saw in the presence of shelter salesmen the "true barbarity" of the family shelter. For Shirer, shelters exposed troubling aspects of class and racial inequality that had long gone unmentioned by OCD spokesmen. With shelter salesmen "threatening to make a racket out of the bewilderment of the American people," Shirer asked the readers of Redbook: "Are only the well-to-do among us to have a chance of survival?" 109 "The entire sales pitch of civil defense," Walt Goodman wrote, was based on "the happy image of father, mother, children, sitting snugly together in their new convertible games room shelter, first aid kit ready but unused." For Goodman, the home shelter market was "based on several grossly inaccurate assumptions." 110 Against a backdrop of public unease, press scrutiny, and a growing distrust of shelter salesmen, the consumer market of civil defense began to decline.

As Kennedy and his New Frontiersmen began to restyle the federal guidelines of civil defense toward collective community shelters, and newspaper coverage increasingly painted an industry desperately in need of policing, the FTC took an active stance on regulating and controlling the home shelter market. After a series of public complaints over shady shelter contractors, which had been printed in the letters page of the New York Times and Washington Post, the FTC set out to differentiate the "official shelter manufacturers" from those operating "outside of OCD guidelines." 111 The FTC intended to catalogue the number of shelter firms operating across the United States; however, the FTC also launched an investigation into the advertisement of home shelters in the early months of 1962. The notion of DIY nuclear survival, already out of favor with the New Frontiersmen of the Kennedy White House, suddenly faced a new level of scrutiny from a federal agency that had little vested interest in seeing the shelter market succeed.

Throughout 1962, Paul Rand Dixon, the chair of the FTC, took a hard line against those salesmen operating outside of OCD approval, dubbed by Los Angeles Disaster Services coordinator Roy Hoover as "suede-shoe boys."112 "Ideologically, we're at war with communism," Dixon stated, adding that promoting "worthless shelters ... comes pretty close to being treason." ${ }^{113}$ Curtailing "fraudulent and dangerous advertisement," 114 Dixon passed two new advertisement guidelines in December of 1961 written, according to a FTC report of the same month, to "limit the layman's language" to OCD guidelines. ${ }^{115}$ Shelter firms caught operating outside of the FTC guidelines faced fines and potential criminal prosecution. The new guidelines were designed to "root the exploiters of human fear out of the picture" and provide "a detailed, clear cut and nationwide civil defense program under the leadership of the federal government."116

\footnotetext{
${ }^{107}$ James Reston, “Those Sweet and Kindly Shelter Builders," New York Times, Nov. 12, 1961, 3.

${ }^{108}$ James Reston, "How to Be Evaporated in Style," New York Times, Oct. 15, 1961, E8.

${ }^{109}$ William L. Shirer, "Let's Stop the Fallout-Out Shelter Folly!," Good Housekeeping, Feb. 1962, 151.

${ }^{110}$ Walt Goodman, "Fallout and Your Family's Health,” Redbook, Mar. 1962, 105.

${ }^{111}$ Thomas Hagen to Pierre Salinger, "RE: Volume of Mail," Aug. 11, 1961, box 595, Civil Defense, Central Subject Files, RG397, NARA 11.

${ }^{112}$ Roy Hoover quoted in Rose, One Nation Underground, 192.

${ }^{113}$ Speech at the Chicago Better Business Bureau, Nov. 14, 1961, box 005, Paul Rand Dixon Papers, 1961-1963, Papers of the Federal Trade Commission (FTC), JFKL.

${ }^{114}$ Advertising Alert, Aug. 12, 1961, box 003, FTC, JFKL.

${ }^{115}$ FTC ruling December 1961, box 001, series 1, The Code of Federal Regulations of the United States of America, Annual Report, FTC, JFKL,13.

${ }^{116}$ Congressional Hearing: House Interstate and Foreign Commerce Committee, Aug. 22, 1961, box 005, FTC, JFKL, 335.
} 
The tightening of FTC guidelines on shelter advertisements indicated a transition within the federal government's approach to civil defense and suggests an additional set of causes for its retreat from placing survival in the hands of private businesses. The moral economy of the shelter business exhibited a pattern in which unscrupulous and exploitative market practices highlighted the failure of government to provide meaningful civil defense to its population. ${ }^{117}$ As recent models of postwar consumer politics have shown, American citizens could make claims upon the state, and policy makers could act on behalf of a consuming public; but consumer activism could also draw federal interest to issues government officials might otherwise choose to ignore. ${ }^{118}$ Even within the OCD, private shelter companies working with trade associations no longer appeared the "solution" to public engagement with civil defense. ${ }^{119}$

Indeed, the media-savvy advisors of the Kennedy administration championed a swift pivot from private to community shelters. During a Hyannis Port Thanksgiving meeting in 1961, Arthur Schlesinger Jr., who had been steadily collecting a box of negative shelter coverage, advised Kennedy that he must realign the administration's position on nuclear security, stating that the question of "shelter ownership has turned ugly." ${ }^{20}$ Schlesinger advised against any further presidential endorsement of DIY shelters and argued that civil defense must be as framed as a form of community welfare. Following Schlesinger's recommendation, Robert McNamara and Steuart Pittman set out to extend federal funding of civil defense by an additional $\$ 700$ million, earmarking new grants for "non-profit health, educational, and welfare institutions that would construct public shelters big enough to house at least fifty people of up to $\$ 25$ per shelter space."121 Kennedy also confirmed that the national shelter survey, designed to identify and stock potential public shelter spaces, would drive policy forward, resulting in the official sanction of fallout shelter signs for public buildings such as schools or hospitals.

David Monteyne astutely describes this shift as part of the "Democrat approach to civil defense." ${ }^{122}$ During the previous Republican administration, family shelters and the gospel of self-help had satisfied both popular concerns over military control by federal agencies and conservative hostility regarding the notion that a massive federal investment in civil defense and new housing developments paved the way toward an expensive militarized New Deal. ${ }^{123}$ Public backlash to the selling of shelters had done much to undercut that vision. Psychiatrist Charles Fritz of the National Academy of Science Disaster Research Group summarized this shift in civil defense discourse by advocating that policy makers "must stop thinking of American society as if it were simply a collection of individuals and families who are individually responsible for the defense of the homeland. The realistic unit of administration and management in a nuclear attack is the nation as a whole." ${ }^{124}$ By the middle of 1962, with tension escalating over Cuba and the politics of civil defense changing, the consumer message of do-it-yourself survival appeared unsustainable.

Predictably, the hardening of the FTC's guidelines on shelters had an immediate impact on the commercial prospects of shelter companies. The OCD-sponsored public shelter exhibits that had been commonplace at state fairs, shopping malls, and veteran centers declined rapidly after March of 1962 when the FTC guidelines took effect. In September of 1961, families

\footnotetext{
${ }^{117}$ Helen Tangires, Public Markets and Civic Culture in Nineteenth-Century America (Baltimore, 2003$), 3$.

${ }^{118}$ See Jacobs, Pocketbook Politics, and Cohen, A Consumers' Republic.

${ }^{119}$ Draft memo for Civil Defense booklet (undated), folder 3: Draft Statements Classified, box W04, Subject Files: Civil Defense, Draft Statements for Civil Defense Booklet, JFKL.

${ }^{120}$ Arthur Schlesinger Jr., "Reflections on Civil Defense," folder 3, box 295, Civil Defense 12/61, National Security Files, JFKL, 1.

121 "First Oral History Interview with Steuart Pittman," Sept. 18, 1970, John F. Kennedy Oral History Collection, JFKL, 6.

${ }^{122}$ Monteyne, Designing for Civil Defense in the Cold War, 36.

${ }^{123}$ McEnaney, Civil Defense Begins at Home, 20.

${ }^{124}$ Charles E. Fritz quoted in David Allison, "Fallout Shelters at Once," Architectural Forum (Feb. 1961$), 127$.
} 
visiting Prince George Mall in Washington, DC, were greeted to a "recording of air raid sirens and exploding bombs" and a looped recording of an "anguished male voice" that shouted: "My wife, my children ... if I'd only listened to civil defense ... I'd be in that shelter now." By the summer of 1962, OCD-sponsored public exhibitions on a similar scale were almost nonexistent, replaced by an emphasis on locating and identifying public spaces that might act as safety zones. ${ }^{125}$ Additionally, private shelter contractors caught operating outside the new FTC guidelines now faced increasingly harsh legal repercussions. In Florida, the Orlando-based firm Survival Shelters ceased operations in March of 1962 after local residents reported that the company had used the official civil defense emblem on its promotional material without OCD authorization. ${ }^{126}$ According to OCD officials, Survival Shelters designed its sales pamphlets specifically "to give the impression that the government had approved of the product" and "must be taken out of circulation immediately." 127 However, for the residents of Orlando, the damage to the reputation of local civil defense efforts was already done.

By the fall of 1962, reports of "suede shoe" salesmen began to drown out positive coverage of reputable shelter firms. Publications with a history of criticizing civil defense, such as The New Republic, Newsweek, Nation, and Commonweal, published articles filled with anecdotes of "gullible homeowners" paying $\$ 850$ for shelters that cost $\$ 180 .{ }^{128}$ Casting shelter salesmen as the true "racketeers" of the Cold War, homeowners purchasing shelters often appeared within these articles as "neurotic men," tricked into making an anxiety purchase that offered little in the way of actual family safety. ${ }^{129}$ The image of the tricked homeowner purchasing a faulty shelter repeatedly surfaced on the eve of the Cuban Missile Crisis, frequently in conjunction with stories of OCD officials inspecting do-it-yourself shelters only to find them unsafe. One account from Consumer Reports recounted how an OCD officer had inspected a $\$ 5,000$-dollar shelter only to deem it a "potential tomb." ${ }^{130}$ Taken together, these articles fueled the perception that shelter owners were not responsible male consumers, but individuals taking part in an activity that was at best "ludicrous" and at worst "immoral."131

Accounts of homeowners deceived by shelter salesmen were not just the subject of media sensationalism; similar accounts can be found in government records of public correspondence during the height of the shelter craze. Unsurprisingly, members of the public who had been sold shelters by sales representatives claiming to speak on behalf of the federal government quickly registered their complaints. In Long Island, Arthur L. Doolittle wrote directly to President Kennedy following his experience with the Port Jefferson-based shelter firm U.S. Fallout Shelter Incorporated. Doolittle, having contacted his local shelter company after seeing an "advertisement in the local newspaper, Newsday, about a shelter for $\$ 495$ which was civil defense approved," was promptly visited by a sales representative claiming to "speak on behalf of the government." 132 The salesman told the family that the $\$ 495$ shelter model was unsuitable, due to a "high roentgen count from living so close to New York City." 133 Claiming to be an expert on all civil defense matters, the salesman confidently informed the family that they should convert the home cellar into

\footnotetext{
125“Survival: Are Shelters the Answer?" Newsweek, Nov. 6, 1961, 19.

${ }^{126}$ Information Bulletin, Sept. 22, 1961, box MF01, FTC, JFKL, 3.

${ }^{127}$ Report: Survival Shelters, July 1, 1962, Mobilization and Manpower Region, box 4, Subject Records of the Office of Defense Mobilization, R397, NARA II.

${ }^{128}$ Margaret Mead, “Are Shelters the Answer?" New York Times Magazine, Nov. 26, 1961, 4; "The Paradox of Civil Defense," Commonwealth, Mar. 1962, 139; I. F. Stone, "Civil Defense Madness," Weekly, Nov. 1961, 13; Linus Pauling, "Shelter Muddle," Dissent, Oct. 1961, 34; "Shelters and Survival: A Report on Civil Defense," New Republic, Nov. 1961, 140.

${ }^{129}$ Norman Cousins, "Shelters, Survival, and Common Sense," Saturday Review, Oct. 21, 1961, 30.

130"Enter the Survival Merchants," Consumer Reports 27, no. 1 (Jan. 1962): 47.

${ }^{131}$ Mead, "Are Shelters the Answer?," 115.

${ }^{132}$ Doolittle to OCD, Nov. 4, 1961, box 12, Central Files 1961-1968, Shelters and Vulnerability Reduction, Record of the Defense Preparedness Agency, OCD, RG397, NARA II, 1.

${ }^{133}$ Ibid., 2.
} 
an underground shelter - a service U.S. Fallout Shelter Inc. could supply for $\$ 2,200$. Balking at the cost, Doolittle told the salesman they could not afford it. The sales representative appealed to Doolittle's paternal responsibility: "their argument was that, as a husband, the safety of my wife and children should come first." Convinced by the sales pitch, the Doolittles agreed to a lower price, paying $\$ 1250$ for a shelter to be built in their cellar. Despite taking out an FHA loan to pay for the shelter, the construction was never completed. Once the frame of the shelter was placed in the cellar, the owners of U.S. Fallout Shelter Inc. came to visit the construction site "stating that it was not built correctly and they would fix it.... Needless to say no one came around to fix it." When the family tried to contact the company, they learned that the U.S Fallout Shelter Inc. had "disconnected its phone line." Neither the Better Business Bureau nor the Civil Defense Officer for Long Island could help. "We are a family of patriots," Arthur Doolittle wrote. "We went ahead with the shelter, and we felt we were acting as good Americans." 134

The experiences of American fathers "duped," as one St. Louis resident stated, into buying useless or incomplete home shelters undermined their identities as savvy postwar consumers. ${ }^{135}$ By 1962, the message of civil defense, with its affirmation of individualism and selfreliance, had instead yielded a situation in which a business class seemingly exploited the fears of a nation. Americans quickly forgot the motives of individual shelter salesmen such as James Cline, who had decided to sell shelters out of a sense of national service, and replaced them with stories of shelter salesmen posing as civil defense officials to make a quick sale. ${ }^{136}$

Just as quickly as they appeared, the shelter sales representatives vanished. Through 1963, business ventures that had opened the doors of new fallout divisions quickly closed them down, often with owners complaining in local papers about a year of lost revenue. The housing market and realtors experienced a similar sudden transition, with the family fallout shelter disappearing almost overnight. But the consumer culture of home survival had gathered such an extensive public backlash that no subsequent president endorsed the building of private shelters. In his drafted, but never publicly delivered statement "Fireside Chat on Civil Defense," Kennedy openly reflected on this transition, referencing the durable impact of the shelter sales representatives on homeland security: "We are not going to permit unscrupulous men to racketeer on people's anxieties over nuclear war." 137

By the time of the Cuban Missile Crisis in October 1962, shelter owners themselves had started to attract a substantial level of criticism. From reports of men stockpiling shelters with weapons and ammunition and embracing a survivalist mentality, to protests on Ivy League campuses across the United States, the family fallout shelter embodied, in the words of Walter Lippmann, the "evil of each family for himself and the devil take the hindmost."138 Those private enterprises that did not fold started to reinvent themselves. Companies selling fallout shelters, especially within the Midwest, quickly rebranded their products as "tornado or hurricane shelters." By the start of 1963, 600 shelter companies nationwide had filed for bankruptcy. ${ }^{139}$ The market for the family shelter was dead.

\section{Salesmen and Survival}

During 1963, one of the most popular stand-up routines for the Chicago-based comedy group Second City was "The Fallout Shelter Salesmen." The performance followed the antics of a

\footnotetext{
${ }^{134}$ Ibid., 3 .

${ }^{135}$ Letter: Author Unknown, Nov. 6. 1961, Shelters and Vulnerability Reduction Sept--Dec, box 14, Central Files 1961-1968, Record of the Defense Preparedness Agency, OCD, RG 397, NARA II.

${ }^{136}$ Balk, "Anyone for Survival?," 75.

${ }^{137}$ Fireside Chat on Civil Defense," box 30, Subject File Civil Defense, Theodore Sorensen Personal Papers, JFKL, 1.

${ }^{138}$ Walter Lippmann, “Mistaken Fallout Shelter Scare," St. Louis Post-Dispatch, Nov. 15, 1961, 141.

${ }^{139}$ Balk, “Anyone for Survival?,” 75.
} 
fictional shelter company, Acme Fallout Shelters, and its owner's attempts to train three aspiring shelter salesmen. ${ }^{140}$ As the scene develops, it becomes clear that one of the sellers is much more adept at selling survival than the others. Not only was the salesman more than happy to offer a money back guarantee to any family whose shelter did not survive a direct nuclear blast, but he was "willing to throw in a free machine gun" to help keep those "pesky" neighbors away. The routine, a guaranteed crowd pleaser in the underground comedy clubs of Chicago and later New York City, illustrates how by 1963 the family fallout shelter had become something of a national joke. ${ }^{141}$

From a nationwide talking point to an object of countercultural satire, the fallout shelter salesman occupies a unique place in the cultural and political imagination of the Cold War. The sharp rise and fall of the home shelter market over the course of two years was far more than a simple narrative of failed expectations, inflated sales rhetoric, and unscrupulous business practices. In the failure to sell survival, consumer incentives were unable to facilitate public engagement with the imperatives of the security state. For Elaine Tyler May, security and democracy in the modern age became rooted in the "principles of individualism, unfettered capitalism, the sanctity of the home, and a suspicion of outsiders that gained salience in the early Cold War." ${ }^{142}$ Yet the history of the home shelter points to a rejection of the promise of private enterprise at the expense of public good. For Molly Geidel, the agenda of nation building, modernization, and development is best understood in terms of a "fantasy" created by policy makers and stimulated by volunteers throughout the developing world to protect American capitalism abroad. ${ }^{143}$ Closer to home, the domestic shelter market was another failed fantasy of Cold War development, manifested in the inability of the shelter salesmen to close a deal.

To dismiss shelter salesmen as indications of wider insecurities, paranoias, and irrationalities is to view them as caricatures of the Cold War home front. Indeed, wedding the principles of consumerism to the promise of nuclear survival seems so absurd that perhaps it is not at all surprising that even the best sellers never truly succeeded. But the outsourcing of security policy to local enterprise at the very height of nuclear tensions attests to the level of faith that policy makers put in capitalist consumer principles as a solution to geopolitical problems. Even so, the domestic Cold War did not always assist the ascent and consolidation of capitalist interests. The family fallout shelter market faltered and stuttered precisely because the consumerist ethos of home survival began to represent the excesses of private business practices. Salesmen failed to recast the Cold War homeowner as defender of the nation, good citizen, or even effective consumer. But their failure also profoundly impacted the language of domestic security. It is debatable whether the United States has or will ever be, in the words of one salesman, "a nation of shelter builders just waiting for the push." ${ }^{144}$ But faced with the intimate and immediate prospect of total annihilation, the nation never embraced the idea that survival in war should be a consumer choice.

Thomas Bishop is a lecturer in American History at the University of Lincoln, UK. He completed his PhD in American studies and history at the University of Nottingham in 2016. His first book, Every Home a Fortress: Cold War Fatherhood and the Family Fallout Shelter, is forthcoming from the University of Massachusetts Press. In 2019 he will be the recipient of an AHRC Kluge Fellowship at the Library of Congress researching his next project on Southern activism and nuclear power in the 1980s.

\footnotetext{
140“Shelter Salesmen," Second City Revue, Jan. 1963, videotape of Second City New York, WNEW-TV.

${ }^{141}$ For more on Second City, see Stephen E. Kercher, Revel with a Cause: Liberal Satire in Postwar America (Chicago, 2010).

${ }^{142}$ Elaine Tyler May, "Security against Democracy: The Legacy of the Cold War at Home," Journal of American History 97, no. 4 (Mar. 2011): 939-57, here 956.

${ }^{143}$ Molly Geidel, Peace Corps Fantasies: How Development Shaped the Global Sixties (Minneapolis, 2015).

${ }^{144}$ Balk, “Anyone for Survival?," 75.
} 